\title{
Brand Elements Model of Professional Football Clubs on Customers Based Brand Equity (CBBE)
}

\author{
Rasool Nazari* \\ Associate Professor, Faculty of Sport Sciences, Islamic Azad University, Isfahan (Khorasgan) Branch, Isfahan, Iran
}

Submission: June 15, 2018; Published: July 03, 2018

*Corresponding author: Rasool Nazari, Associate Professor, Faculty of Sport Sciences, Islamic Azad University, Isfahan (Khorasgan) Branch, Isfahan, Iran; Tel: (00)989133680240; Email: nazarirasool@yahoo.com

\begin{abstract}
The aim of this study is to provide the elements are redirected to football clubs on the basis of brand equity from the customer perspective (CBBE). This study applied a statistical correlation-survey population consisted of all mangers, the club staff, players and fans and customers four sports and cultural club Sepahan, ZobAhan, Gitipas and Reef. Cochran formula was applied to define the sample volume due to uncertainty of the number of individuals. Instrument components are based on customer-based brand equity Claire (2001) consists of 71 questions. The validity by two professors of sport management and reliability was confirmed by Cronbach's alpha coefficient 0.92 respectively. The findings for statistical analysis SPSS software and LISREL software was used to model. In this study, six of brand salience, brand performance, brand imagery, judgments about brand, brand perceptions and brand conformity as presented in predicting brand equity from the customer perspective ( $\mathrm{p} \geq 0 / 05)$. In general research indicate that among the six operating components are the building blocks of conformity with commitment has the greatest impact and the quality of imaging components are operating judge had minimal impact on brand equity from the customer perspective.
\end{abstract}

Keywords: Brand; Equity Values; Clubs; Customer; Football

\section{Introduction}

In recent decades, researchers and operators of service section have attended strongly to the brand issues. In fact, the brand possesses a value higher than the conventional value of a property that is created through the occupational financial activities [1]. Establishment of a powerful brand in the market is the main goal of many organizations. Therefore, specialists believe that a commercial brand could initiate the value more than the common value. Nowadays, brand is not only an efficient instrument available for the managers. Brand is a strategic requirement that aims the organizations to create more value for the customers and also providing stable competitive advantages [2]. The role of brand equity in the service organizations is of outmost importance, because services have some unique characteristics that are resulted from the direct cooperation of employees with the customers. The brand equity refers to a set of assets related to the name and sign of the brand add the value of the product, service or customers to it. In service sector, the customers usually take their purchasing decision based on their perception from the brand of the company [3]. Brand provides a set of claims and commitments and addresses to reliability, stability and a defined set of expectations. This set of claims and commitments include the characteristics that the buyer purchase and result in the customer's satisfaction [4]. Keller [5] states the
Customer-Based Brand Equity as: "a different effect of brand awareness on the customer response to marketing". A proper brand for a company provides various advantages including financial advantages for the company. Another advantage of brand is the priority to select this company among the similar companies [6]. Design and establishment of powerful brands are the main priorities of most of successful organizations, because it could add some competitive advantages to the general perception of powerful brands. Therefore, sport managers should manage the teams, leagues and assets from the view of a brand [7].

Brand conformity pattern (brand resonance) of Keller [2] considers the brand establishment as a stepped process in that the steps fix from down to up. These steps include: to ensure that the brans is recognized by the customers and connecting the brand a specific stage or need in the customers mind, creating the meaning of the brand in the customers mind by connecting a set of tangible and intangible characteristics to the brand, extracting the desired response from the customers in terms of judgments and emotions, transforming the brand response to provide a deep connection between the customer and the brand [8]. Six footstones of the customer-based brand equity pyramid include: brand prominence, the degree to which that the brand 
is noticed when and with which feelings or in which buying or usage circumstances? Brand performance, how a service or product can fulfill the production or functional needs of the customers? Brand image, the image relates with the exterior belonging of the service or product and refers to the directions in that the brand pass to fulfill the social and psychological needs of the customers. Brand judgments, it focuses on the personal believes and assessments of the customers, Brand feelings, the emotional responses and reactions of the customers toward the brand. Brand resonance, the identity of the relation between the customers the brand and also the degree of customer's resonance feeling with brand. Brand resonance includes the depth of internal and psychological relation of the customers with the brand [9].

Nowadays, brand management has attracted many followers in marketing field and many theorists, managers and researchers have considered the next domain of marketing as the brand management world and branding affairs. Possibly, no investment could be efficient more than a powerful, reliable and valuable name for organizations. Less vulnerability in competitive circumstances of the market, more profit margin, stronger communications are other benefits of brand development. . Various researches are conducted in the field of branding, namely Maja [10] in study of Customers Based Brand Equity (CBBE) concluded that the brand function is the positive factor in increasing the brand equity from customers perspective. Moreover, Philip Wong [11] reported the effect of destination competitiveness on CBBE from the positive effect of decreasing price sensitivity and increasing customer loyalty on increasing CBBE. Also, Zhuowei [12] concluded according to the CBBE model that brand image and brand awareness has significant positive effect on increasing the CBBE. Along this, Bianchi [13] has pointed that brand image has significant effect on increasing the CBBE. Brand alliance, sometimes named co-branding, occur when two brands or more allegiant together and do all their marketing activities together in any possible way.

Marketing researches in the sport field shows that the followers are the main agents that purchase the ticket and attend in the stadium to support their favorite team. Therefore, the necessity to noticing the brand of the club can be considered as a motivating factor in regular and continued attendance of the followers. The importance of brand is more significant when it relates directly to the quality of the playing of the team and cause that the followers create an emotional connection with the team through the brand [14]. In this regard, Farahani et al. [1] reported in a study titled as "modelling of followers-based brand equity in Iran's sport clubs (FBBE)" and stated that two factors of specifications and the interests of brand associations has no significant effect on brand loyalty among the followers of Iran Football Premier League, but two factors of brand identity and attitudes of brand association have significant effect on brand loyalty among the followers of Iran Football Premier
League. Meanwhile, Seifi [15] concluded in a study titled as "the effect of financial support on CBBE about the viewers of Mahram Basketball Team Competitions" that among six factors of prominence, performance, image, judgments, feelings and resonance of the brand, the brand prominence has the most effect on brand equity. Brand possesses strategic value for organizations, brand could be considered as an important part in intangible assets of the organizations. Brand is the agent of exclusive property of the product or service for organizations.

Brand has exceeded the geographical boundaries and could be considered internationally and globally [16]. While football is a popular sport in Iran and due to the fact that sport clubs are mainly make benefit through ticket selling and financial supports, so a team with a powerful brand could attract great audiences in stadiums that lead to more income for the club. Raising a brand is a main motive for sport clubs as a sport organization to move toward success. Because intensive competition in football market cause that brand equity be advisable for sport clubs.

It seems that sport brand can go beyond from a city or province and be attended nationally. Regarding the mentioned issues, it seems that brand equity is not distinguished for professional football league clubs and it is more not only as an intangible asset, but also an asset with undetermined value. Therefore sport clubs can distinguish through CBBE how they competitors became distinct from the others and which factors are affecting efficiently their brand quality. The present paper seeks to provide a model of the brand elements of four wellknown football clubs in Iran named as Sepahan, Zob-e Ahan, Gitipasand and Rif in Isfahan to take step in recognizing of this section of football industry of the country. The research question refers to the point that how much is the effect of the brand elements of professional football clubs on customers-based brand equity in these clubs?

\section{Methodology}

The present study is an applied research regarding the purpose of the study, because it refers to development of applied knowledge in a specific field and a descriptive research regarding data gathering method and a correlation research regarding the identity of the study, because the purpose of this study is to discover the relationship between different variables that will be conducted as survey. The population of the present study includes all the managers, employees, players and followers of four football clubs in Isfahan named as Sepahan, Zobe Ahan, Gitipasand and Reef. Cochran formula was applied to define the sample volume due to uncertainty of the number of individuals. The sample volume was defined as 384 according to Cochran formula. Stratified random sampling method was applied to select the samples. Brand elements questionnaire based on CBBE presented by Keller [2] was used and the questionnaire was presented to 10 specialties in the field of sport management to define the reliability of the researcher-made questionnaire for 
confirmation of face and content validity of the sample. These specialties have studied the items of the questionnaire regarding the purpose of the research in terms of face and content validity. The questionnaires were studied by dividing 30 items from the considered sample, the primary study was distributed and after collecting the questionnaires, they were calculated through Cronbach's Alpha (Reliability 0.90). All data were analyzed by Statistical Package for Social Science SPSS 19 and Lisrel Software 8.54 .

\section{Results}

The descriptive data for the gender of the individuals show that $71 \%$ of the participants of the study are male and $27 \%$ are female. For the age of the participants, the maximum frequency was observed in the group of 31 to 40 years old (32\%) and the minimum frequency relates to the age group of less than 20 years old $(4.7 \%)$. The maximum frequency observed for the education level relates to the group with bachelor degree (38\%) and the minimum frequency relate to $\mathrm{PhD}$ group (less than 1\%). At first, kolmogoroff - smirnoff test was applied for normality of the sample and Levene's Test was applied for homogeneity of variance $(\mathrm{p} \leq 0.05)$. According to the results, the statistical sample of the study follows the normal distribution and all the variables of the study have homogeneity of variance. According to Table 1, it is evident that brand excellence aspect of the brand judgments components has the most average and quality aspect from the judgments components of the brand has the minimum average.
Table 1: Descriptive Table for the Components of the Model.

\begin{tabular}{|c|c|c|c|}
\hline \multicolumn{2}{|c|}{ Component } & Average & $\begin{array}{c}\text { Standard } \\
\text { Deviation }\end{array}$ \\
\hline \multicolumn{2}{|c|}{ Brand Prominence } & 3.6430 & 0.91168 \\
\hline \multicolumn{2}{|c|}{ Brand Performance } & 3.4105 & 0.83331 \\
\hline \multirow{4}{*}{$\begin{array}{c}\text { Brand } \\
\text { Judgments }\end{array}$} & Quality & 3.2347 & 0.82529 \\
\cline { 2 - 4 } & Credit & 3.4934 & 1.00926 \\
\cline { 2 - 4 } & Brand & 3.6303 & 0.96513 \\
\hline \multirow{2}{*}{ Brand Feelings } & Excellence & 3.6536 & 1.07394 \\
\hline \multirow{3}{*}{$\begin{array}{c}\text { Brand } \\
\text { Resonance }\end{array}$} & Loyalty & 3.4571 & 1.12 \\
\cline { 2 - 4 } & Dependence & 3.5750 & 1.00444 \\
\cline { 2 - 4 } & Society & 3.3523 & 1.08635 \\
\cline { 2 - 4 } & Commitment & 3.6201 & 1.12964 \\
\hline \multicolumn{2}{|c|}{} \\
\hline
\end{tabular}

Figure 1 demonstrates the main model of the research. In the present research, the significance of the coefficients and parameters obtained from the measurement of communicative skills, quantum management and organizational agility were reported in standard coefficients estimation mode and it was found that this model is well fitted. Regarding the output of Lisrel model, the amount of chi 2 of the calculated degrees of freedom was equal to 2 . This low amount demonstrates the wellfitting of the model. Also, because the observed significance of the model was higher than the standard amount (0.05), so it could be concluded that the presented model is a proper model.

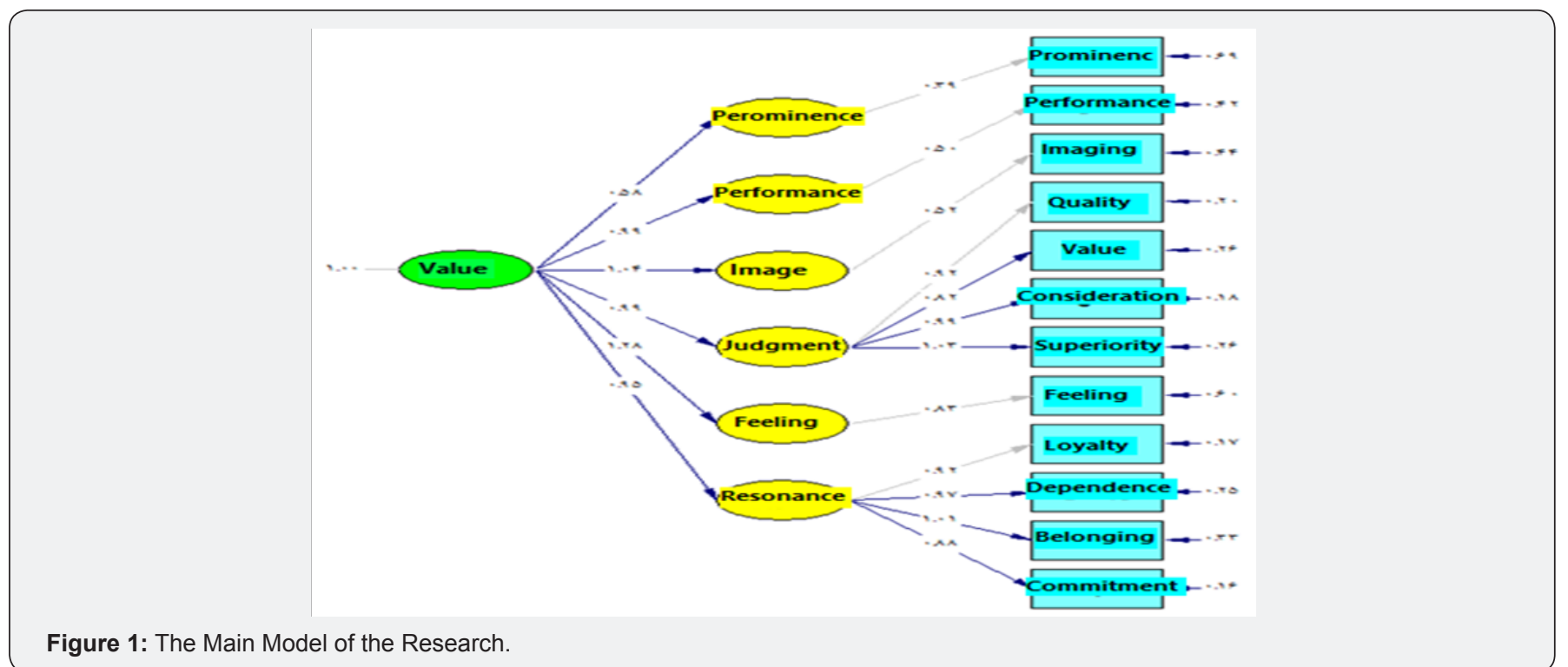

Table 2 shows the amount of most important scales of model fitting. As it is evident, all the scales have brought the required and desired limit that means that the data support the research model properly. In other word, the research model with the existing graphical diagram is acceptable and next stage could be allocated to evaluate the research hypothesizes. After fitting of model, factor loading of every variable was considered to measure the suitability of research data or in another word, to evaluate if the research questions that were applied to measure the research variables are chosen and designed properly or not. Factor loading demonstrates the amount that is loaded on the latent variable. This amount refers to variance changes of each 
observed measuring variable that are examined by the latent variable. The comparison of this amount with minimum amount of 0.5 will assist in decision making regarding the lasting of the observed variable. In other words, the researcher should decide about removing the observed variables with amount less than 0.5 and therefore evaluate the validity of its structures. The output of Lisrel software in this stage is demonstrated in following table. T-test statistic is used to show the significance

Table 2: Important Scales of Fitting. of each parameters of the model. This statistic is obtained from the proportionate of each parameter's coefficient to the standard deviation error of that parameter that should be more than 2 in t-test and more than 1.96 in Z-test to be statistically significant. Regarding the output of Lisrel software, the $t$ amount was calculated more than 2 in all variables, therefore all the presented estimations are significant in terms of statistics.

\begin{tabular}{|c|c|c|c|c|}
\hline Indexes Grouping & Index Name & Acronym & Indexes for Model Fitting & Acceptable Fitting \\
\hline \multirow{3}{*}{ Absolute Fitting Indexes } & Goodness-of-Fit Index & GFI & 0.94 & $\% 90<\mathrm{GFI}$ \\
\hline & Adjusted Goodness-of-Fit Index & AGFI & 0.91 & $\% 90<$ AGFI \\
\hline & Root Mean Squared Residual & RMR & 0.004 & $\% 5>$ RMR \\
\hline \multirow{5}{*}{ Comparative Fit Indexes } & Tucker-Lewis Index & NNFI (TLI) & 0.94 & $\% 90<\mathrm{NNFI}$ \\
\hline & Normed Fit Index & NFI & 0.95 & $\% 90<\mathrm{NFI}$ \\
\hline & Comparative Fit Index & CFI & 0.94 & $\% 90<\mathrm{CFI}$ \\
\hline & Incremental Fit Index & IFI & 0.94 & $\% 90<$ IFI \\
\hline & Bentler \& Bonett Fit Indexes & $\mathrm{BBI}$ & 0.93 & $\% 90<\mathrm{BBI}$ \\
\hline \multirow{5}{*}{ Parsimonious Fit Index } & Root-Mean-Square Error of Approximation & RMSEA & 0.090 & RMSEA $<\% 10$ \\
\hline & p-value & $\mathrm{P}$ & 184.10 & \\
\hline & Degree of Freedom & Df & 71 & \\
\hline & Normed Chi-Square to Degree of Freedom & $\mathrm{CMIN} / \mathrm{df}$ & 2 & $1<\mathrm{CMIN} / \mathrm{df}<3$ \\
\hline & Parsimonious Normed Fit Index & PNFI & 0.76 & $\% 05<$ PNFI \\
\hline
\end{tabular}

\section{Conclusion}

The brand prominence is recognized as one of the factors of CBBE. Based on the output of Figure 1 and Table 2, the effect of customer-based brand superiority of professional football clubs were calculated and it could be concluded that brand equity of professional football clubs was significant $95 \%$ in the model and has positive effect on CBBE and has more effects on brand prominence, brand performance, brand imaging, brand judgments, brand feelings and brand resonance has more effects on brand feeling.

Azizi et al. [9] has reported the priority of brand equity as follows: brand image, brand resonance, brand prominence, brand feelings, brand performance, brand judgments. Moreover, Seifi [15] concluded that among six factors of brand prominence, brand performance, brand imaging, brand judgments, brand feelings and brand resonance, it could be said that brand prominence has the most effect on brand equity. In this regard, Jalali Farahani et al. [1] has concluded in a research titled as "modelling of brand equity" that two factors of brand image and brand awareness has positive and significant effect on increasing the CBBE. It is worth to mention that the results of this part of the study are not in conformity of the priority of six factors of the proposed brand in mentioned researches.

It should be noted that the tendency and demand of those customers with higher familiarity and knowledge about the products will be increased. Increasing the awareness and familiarity about the brands of the clubs will be assured through the repetition of connection and presence. In other words, if the consumer experiences of a brand increased through visiting, hearing or thinking, the probability of stabilization of that brand in the mind will be increased. The product forms the main core of brand equity concept, because what the consumer experience from the brand, what hear from the others about the brand and what the football clubs can transfer to the customers by their own relations with the brand, all of them are influenced by the product, therefore, it could be acknowledged that football clubs investigate the amount of performance among the customers to conceive that if it was able to fulfill its success requirements or not. Mental imagery refers to the exterior characteristics of the products same as the way that the customers fulfill their social and psychological needs. This factor demonstrates the method of people's thoughts and imaginations about the brand and it considers less about the people's attitude about the realities despite the brand performance. In this regard, mental imagery refers to intangible aspects of a brand and consumers achieve the mental imageries directly or indirectly. If the consumers think more deeply about the information related to a product and communicate close relationship between this information and their existing knowledge of the brand, stronger associations of the brand will be formed in their mind.

Based on the results, brand imaging was considered as an important and effective factor on CBBE in football clubs. Specific associations of the brand and the strength amount 
of such associations relates to not only their power, but also to the consideration condition of each one toward the brand. Kimpakorn \& Tocquer [17] addresses to the point that personal experiences can provide deep associations from the characteristics and advantages of the brand in the mind and has significant effect on decision making of the con summers.

Judgments about the brand refer to reporting the individual believes and assessments of the customers from the performance, associations and mental images of the brand. Customers' attitude is the result of the general adding of the advantages and specific characteristics of the brand. While the customers have a set of attitudes in their mind, but the most important attitudes that have close relationships with the perceived quality, customer value and its satisfaction have the most important role in brand equity. The feelings toward the b rand can begin with experimental feelings, same as warmth, entertainment, and thrill and end with inner feelings same as security, social acceptance and self-esteem. Regarding the resonance as one of the most effective factors on CBBE in the present research and based on studies of Dezz [18] stating that the customers have desirable feelings toward the supportive team, it could be said that this desired feeling is effective on their purchasing intention. Therefore, it could be acknowledged that the resonance can easily approach the brand to the consumers mind with proper pointing. This issues effects on the brand position and leads to creating a positive image. Brand resonance requires a specific regularity in the activities of the club s, begins with emphasis of the club on behavioral loyalty as the start point and associates with belonging to association among customers $[19,20]$.

It should be noted that the tendency and demand of those customers with higher familiarity and knowledge about the products and services of Football Clubs will be increased. Increasing the awareness and familiarity about the brands of the clubs will be assured through the repetition of connection and presence. In other words, if the consumer experiences of a brand increased through visiting, hearing or thinking, the probability of stabilization of that brand in the mind will be increased and consequently, the professional clubs should increase the awareness level of its customers about the considered brand by applying appropriate marketing programs. Mental imagery refers to intangible aspects of a brand and consumers achieve the mental imageries directly or indirectly. If the consumers think more deeply about the information related to the products and services of the sport clubs and communicate close relationship between this information and their existing knowledge of the brand, stronger associations of the brand of the considered sport club will be formed in their mind. Two factors that strength the associations of different information in the mind of customers could refer to the relation of these information with the details of the individual's life and the degree of agreement among them during the time. Specific associations of the brand and the strength amount of such associations relates to not only their power, but also to the consideration condition of each one toward the brand. While the customers have a set of attitudes about the brands of the clubs in their minds, but the most important attitudes that have close relations with perceived quality, customers value and its satisfaction, have a critical role in brand equity that is the same as judgments toward the brand that could be positive or negative. Customers have pleasant feelings about their favorite team and such pleasant feeling will effect on their purchasing decision. This pleasant and positive feeling is the result of positive judgments toward the brand of the considered sport club. Brand resonance requires a specific regularity in the activities of the club s, begins with emphasis of the club on behavioral loyalty as the start point and associates with belonging to association among the customers. Product is the heart of brand equity. Football clubs should attend in design, production, marketing, sale and presentation of their sport products and services in a way that provide a positive image of the brand and create powerful, desirable and unique mental associations in the mind of the customers.

Professional sport clubs should fulfill all their promises to increase CBBE and accept all the opinions and comments of their customers. While many studies have emphasized on the importance of loyal customers for the organizations and have stated that high number of loyal customers for an organization is considered as a valuable asset and loyalty to the brand is one of the important aspects in creating brand equity. Loyalty can provide an opportunity for the sport clubs to enact against the threats same as competitions, because if the customers be more loyal toward a brand, they are less sensitive against the price increase due to the kind of service that fulfill their needs and is proportionate to their expectations. Therefore, service sections can consider the customers' demands to create loyalty in customers and try to resolve the demand of each person based on his/her own needs. Moreover, they can provide special benefits planning for loyal customers, gift and appreciation of loyal customers and in this way they can attract their feelings of trust and loyalty. Also, they can prove their altruistic goals to the customers by communicating with the customers and public relations and facilitate the loyalty feeling by providing the trust.

It seems that professional football clubs can consider the proposed model in Figure 2 to promote the strategic position of brand equity. They also can create a bright image from the club's performance in the mind of the followers by distinguishing the brand of the club and excite the feelings of the customers by providing sincerity and warmth, social acceptance, respect, exciting conditions and finally security. In this regard, it should be considered that the judgments by the customers toward the brand are influenced by brand excellence, quality, reliability and social confirmations and acceptance toward the brand. It should be stated that the football clubs should provide brand loyalty, brand belongingness, brand dependence and stable relation with the brand to provide the required conditions for stable resonance to the brand by the customers. 


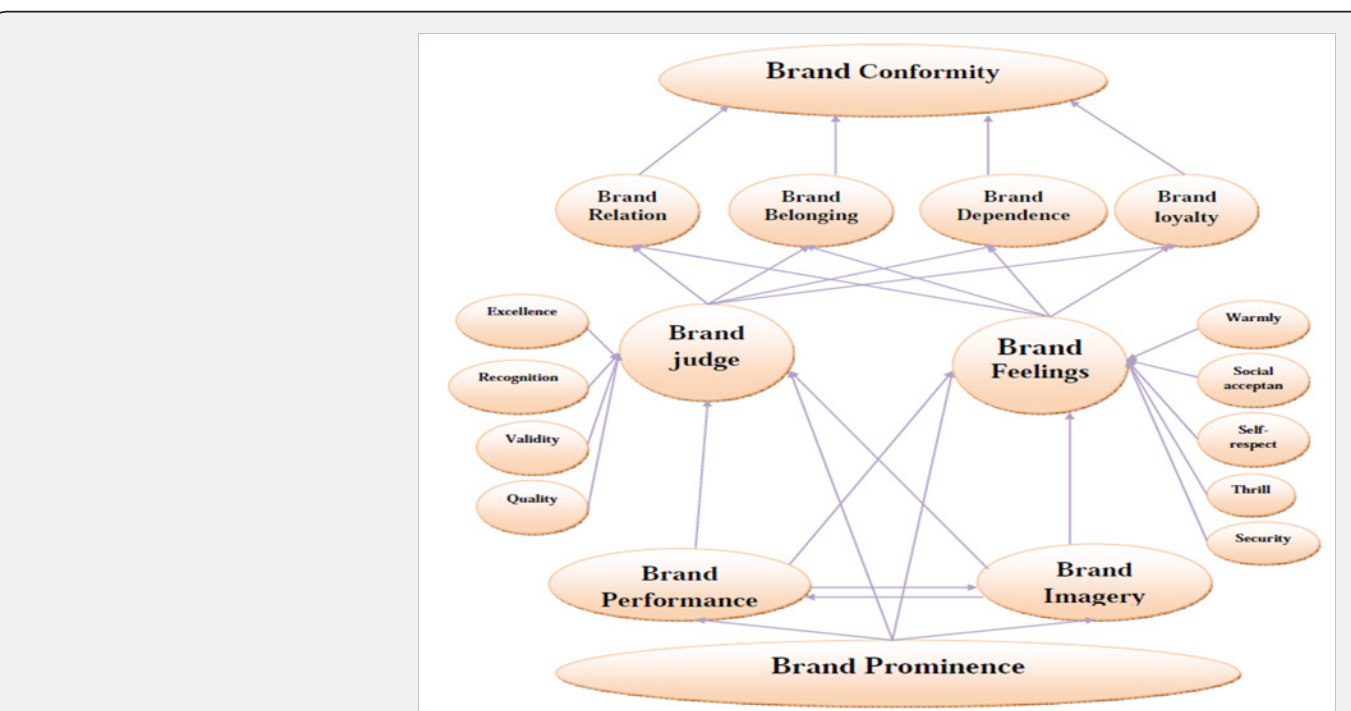

Figure 2: The Proposed Model of the Research.

While the brand resonance results in effect on the selection of the brand by the customers, in this regard, one of the ways to increase awareness level of the customer of the brand is expanded advertisements to introduce and present the brand. In the conditions that customer has little information of the brand and the way in which services are provided, familiarity with the brand and providing information are the proper answer to increase the awareness level. Brand association includes the factors that are connected with the name and image of the brand in customer's mind. Different factors should be considered to increase the brand association in customers' mind including considering the type of service, endeavor to make the intangible services as tangible services, related prices to services, geographical region and reputation.

They can promote the strategic position of the football clubs brands by distinguishing brand alliance with highly reliable brands in service and production fields if the mutual trust between the club and audiences, attending in social and communicative procedures with the followers, keeping the gained reputation in competitive environment be attended and considered by the strategic managers of the club.

\section{References}

1. Farahani A, Ghasemi H, Honari H, Khodadadi M (2014) Modelling of FBBE in Iran's Footbal Clubs. Applied Research Journal in Sport Management 3(3): 51-65.

2. Keller K, Lehmann D (2005) Brands and Branding: Research Findings and Future Priorities. Marketing Science 25(6): 740-759.

3. Kayaman Ruchan, Arasli H (2007) Customer based brand equity: Evidence from the hotel industry. Managing Service Quality 17(1): 92129.

4. Kim Y, Kim C (2006) A Study on the scale development of hotel brand equity using ZMET. International Journal of Tourism Sciences 7(1): $1-28$.

5. Keller K (2010) Building Customer-Based brand equity. Marketing Management 12(2): 14-19.
6. Morovati A, Keshvarshahi M, Rastegar M (2011) Relation of Brand Equity Aspects and Organization Performance base on CBBE (case study: vehicle insurance companies). Research-Scientific Seasonal Magazine of Kavosh 6(3): 1-22.

7. Bridgwater S (2010) Football Brands, Warwick Business School, University of Warwick, UK, Printed and Bound in Great Britain by CPI Antony Rowe, Chippenham and East bound ISBN p. 11.

8. Tong X, Hawley J (2009) Measuring customer-based brand equity: Empirical evidence from the sportswear market in China. Journal of Product \& Brand Management 18(4): 262-271.

9. Azizi Sh, Azhini A (2012) Function of Brand Equity Pyramid of Keller in Iran Saderat Bank. General Management Journal 17(5): 121-134.

10. Maja S (2014) How can integrate Marketing Communications \& advanced technology influence the creation of CBBE? Journal of Hospitality Management pp. 102-129.

11. Philip P Wong, Kenny $T$ (2015) The influence of destination competitiveness on CBBE. Journal of Destination Marketing \& Management 4(4): 206-212.

12. Zhuowei H (2015) Modeling customers: Based Brand Equity for multinational hotel brands. Journal of tourism management 46: 431443.

13. Bijunaci Mohan A (2015) The impact of CBBE on the operational performance of FMCG companies in India. The international Journal of management p. 1-19.

14. Gladen J, Funk D (2001) Understanding Brand Loyalty in Professional Sport: Examine the Link between Brand Associations and Brand Loyalty. International Journal of Sport Marketing \& Sponsorship 3(1): 67-94.

15. Seifi T, Esfahani N, Honari H (2014) The Effect of Financial Support on Mahram CBBE. $4^{\text {th }}$ Banking Services Marketing International Conference. Applied Research Journal in Sport Management 2(4): 87101.

16. Bodet G, Chanavat N (2010) Building global football brand equitylessons from the Chinese market. Journal of Marketing and Logistics 22(1): 8-24.

17. Kimpakorn N, Tocquer G (2010) Service brand equity and employee brand commitment. Journal of Services Marketing 24(5): 378-388.

18. Dezz N (2004) Sponsorship effectiveness measurement scale in sport. European Journal of Marketing 33(4-3): 291-313. 
19. Zayerkabe S, Abdoli M, Sarmad H (2012) Effect of Services Quality on CBBE.
20. Yong J, Kyoungate K (2008) The effect of sport involvement, sponsor awareness \& corporate image on intention to purchase sponsor's products. International Journal of sport 9(2): 20-34.

Your next submission with Juniper Publishers will reach you the below assets

- Quality Editorial service

- Swift Peer Review

- Reprints availability

- E-prints Service

- Manuscript Podcast for convenient understanding

- Global attainment for your research

- Manuscript accessibility in different formats ( Pdf, E-pub, Full Text, Audio)

- Unceasing customer service

Track the below URL for one-step submission https://juniperpublishers.com/online-submission.php 